\title{
Effect of spatial soil variability, incline of slopes and seismic stimulation on permanent seismic slope displacement.
}

\author{
Alamanis Nikolaos Ph.D., M.Sc., P.E., \\ Lecturer, Department of Infrastructure \\ Engineering of Larissa,
}

TEI (Technological Institute of Applied

Sciences) of Thessaly, Greece.

\begin{abstract}
The parameters of shear strength, even within the same soil layer, will vary from point to point as a result of the natural heterogeneity of the materials. Stochastic methods have been introduced to calculate the uncertainty and spatial variability of soil parameters [1]. As opposed to deterministic methods, probabilistic methods allow the selection, based on the specifications of each project, of an acceptable risk level. Moreover, such methods are consistent with the concept of risk parameters of soil vibration and constitute their extension at the fault indicators level, being directly related to the performativity of constructions [2]. The main objective of this paper is to investigate the effect of spatial variability of soil, the slope of the banks and of seismic excitation on permanent seismic displacements [3]. The calculation of permanent displacements within probabilistic frames is achieved by combining the Local Average Subdivision (LAS) algorithm introduced by Fenton and Vanmarcke in 1990 [4] and finite difference software FLAC (Fast Lagrangian Analysis of Continua) used in this paper [5].
\end{abstract}

Keywords: slope incline, uncertainty, stochastic methods, spatial variability, seismic stimulation, permanent seismic displacement.

\section{INTRODUCTORY NOTIONS}

This paper investigates the effect of spatial variability of soil properties, the incline of the slopes, as well as the intensity and content of seismic frequency excitation on developing permanent displacement. For this purpose, static and dynamic simulations of a significant number of slopes with spatial variability of properties are analyzed and the results are compared with their equivalent of homogeneous slope analyses. The performance criterion under dynamic conditions is the residual displacement of the mass of the slopes at the end of seismic vibration. Based on

\author{
Dakoulas Panos Ph.D., M.Sc., P.E., \\ Professor, Department of Civil Engineering, \\ University of Thessaly, Greece.
}

experimental results of soil characteristics from the bibliography and use of the LAS methodology and the Mathematica program [6] , an extensive range of random fields was created via an automated process to express the spatial variability of soil properties with the desired characteristics. Then, by using the random fields territorial properties, a new automated process was created through which a large number of numerical simulations for the seismic analysis of slopes was carried out. The spatial variation of properties, as demonstrated through numerical simulations, significantly impacts the values of permanent displacements that appear when the slope is stimulated with a series of historical recordings of seismic vibrations as shown below.

\section{EFFECT OF SPATIAL VARIABILITY OF SOIL PROPERTIES OF SLOPES IN SEISMIC DAMAGE}

The parameters examined with regard to their impact on permanent seismic displacement are as follows:

1. Spatial variability of properties.

2. The characteristics of autocorrelation lengths $l_{x}$ and $l_{y}$

3. Slope of the bank

4. The magnitude of the maximum seismic acceleration.

5. The characteristics of seismic excitation (frequency content).

\subsection{Data of parametric analysis}

Initially we present the parametric analysis data used for the resolutions. Taken into account are average values and variances of spatially-varying standard variables like: cohesion $\mathrm{c}$, internal friction angle $\varphi$, density $\rho$, modulus of elasticity 
Proc. of the Sixth Intl. Conf. Advances in Civil, Structural and Mechanical Engineering - CSM 2018 Copyright $(\odot$ Institute of Research Engineers and Doctors, USA. All rights reserved. ISBN: 978-1-63248-150-4 doi: 10.15224/978-1-63248-150-4-25

Young E, while for the sake of simplicity the values of the diastolic angle $\psi$ and Poisson's ratio $v$, are taken as constants. Average values $\mu$ and standard dispersions $\sigma$ of soil properties, and the $\sigma / \mu$ ratio are given in Table 1.

In table 2 the values of correlation coefficients $\rho_{i j}$ between $\mathrm{i}$ and $\mathrm{j}$ parameters based on published experimental data are presented. Correlation coefficients values for which no experimental data have been found, such as between $E$ and $\rho$, are taken as equal to zero.

Table 3 gives the values of spatial variability (autocorrelation) lengths $l_{x}, l_{y}$ in the horizontal and vertical directions respectively

TABLE 1. AVERAGE VALUES AND STANDARD DISPERSION OF SPATIALLY-VARYING VARIABLES OF SOIL SLOPES. [7]

\begin{tabular}{|l|l|l|l|}
\hline Parameter & $\begin{array}{l}\boldsymbol{\mu} \\
\text { Average } \\
\text { value }\end{array}$ & $\begin{array}{l}\boldsymbol{\sigma} \\
\text { typical } \\
\text { dispersion }\end{array}$ & $\begin{array}{l}\boldsymbol{\sigma} / \boldsymbol{\mu} \\
\text { coefficient } \\
\text { of variation }\end{array}$ \\
\hline $\mathrm{c}, \mathrm{kPa}$ & 30 & 9 & 0.3 \\
& $\mathbf{4 0}$ & $\mathbf{1 2}$ & $\mathbf{0 . 3}$ \\
& 50 & 15 & 0.3 \\
\hline \multirow{2}{*}{, degrees } & $20^{\circ}$ & $4^{\circ}$ & 0.2 \\
& 35 & $\mathbf{6}$ & $\mathbf{0 . 2}$ \\
\hline$\psi^{\circ}$, degrees & $\mathbf{0}^{\circ}$ & 7 & 0.2 \\
\hline \multirow{2}{*}{$, \mathrm{kg})^{\mathrm{m} 3}$} & 1800 & 180 & 0 \\
& $\mathbf{2 0 0 0}$ & $\mathbf{2 0 0}$ & 0.1 \\
\hline \multirow{2}{*}{$\mathrm{E}, \mathrm{kPa}$} & 2200 & 220 & 0.1 \\
& 40000 & 8000 & 0.2 \\
\hline $\mathrm{V}$ & 80000 & 16000 & 0.2 \\
\hline
\end{tabular}

TABLE 2. CORRELATION OF SOIL PARAMETERS

\begin{tabular}{|l|c|c|c|c|c|}
\hline \multicolumn{6}{|c|}{ Correlation factor $\rho_{i j}$} \\
\hline Parameter & $\begin{array}{l}\mathrm{c} \\
(\mathrm{KPa})\end{array}$ & $\varphi^{\circ}$ & $\begin{array}{l}\rho \\
(\mathrm{KN} / \mathrm{m} 3\end{array}$ & $\begin{array}{l}\mathrm{E}(\mathrm{K} \\
\mathrm{Pa})\end{array}$ & $\mathrm{v}$ \\
\hline $\mathrm{c}$ & 1 & -0.5 & 0.5 & 0.2 & 0 \\
\hline$\varphi^{\circ}$ & -0.5 & 1 & 0.5 & 0.2 & 0 \\
\hline$\rho$ & 0.5 & 0.5 & 1 & 0 & 0 \\
\hline $\mathrm{E}$ & 0.2 & 0.2 & 0 & 1 & 0 \\
\hline $\mathrm{v}$ & 0 & 0 & 0 & 0 & 1 \\
\hline
\end{tabular}

TABLE 3. PAIRS OF AUTOCORRELATION VALUES USED IN THE RESOLUTIONS.

\begin{tabular}{|l|l|l|l|}
\hline Lengths of spatial correlation & & & \\
\hline$l_{x}, \mathrm{~m}$ & 20 & 40 & 20 \\
\hline$l_{y}, \mathrm{~m}$ & 2 & 2 & 4 \\
\hline
\end{tabular}

TABLE 4. GEOMETRIC ELEMENTS OF SLOPES

\begin{tabular}{|l|l|l|l|}
\hline & $\begin{array}{l}\text { Inclination } \\
\text { of a slope }\end{array}$ & $\begin{array}{l}\text { Slope } \\
\text { height }\end{array}$ & $\begin{array}{l}\text { Gradient } \\
\text { slope angle }\end{array}$ \\
\hline Geometry A. & $2: 1$ & $20 \mathrm{~m}$ & $26.56^{\circ}$ \\
\hline Geometry B & $1: 1$ & $30 \mathrm{~m}$ & $45^{\circ}$ \\
\hline Geometry C & $4: 3$ & $30 \mathrm{~m}$ & $36.87^{\circ}$ \\
\hline
\end{tabular}

Table 4 gives the characteristics of the three different slope geometries used in the analyses. The corresponding numerical discrepancies of the geometry for cases A, B and C of Table 4 are shown in Figures 1, 2 and 3. In each crosssection of the slopes, a few characteristic points $(\mathrm{A}, \mathrm{B}$, and $\mathrm{C})$ are given in which the seismic response time has been calculated for further processing.

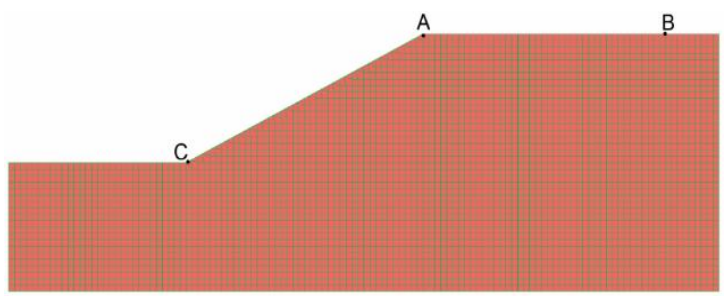

Figure 1. Geometry A: Discrimination of slope geometry with a 2:1 slope.

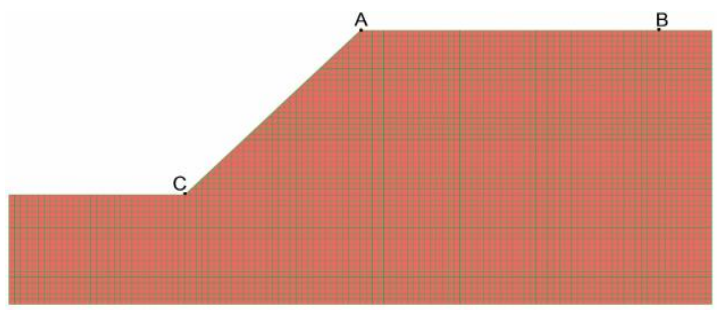

Figure 2. Geometry B: Discrimination of slope geometry with 1:1 slope.

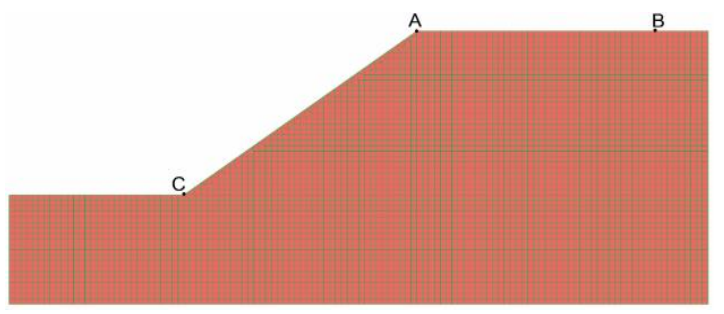

Figure 3. Geometry C: Discrimination of slope geometry with 4:3 slope. 
Proc. of the Sixth Intl. Conf. Advances in Civil, Structural and Mechanical Engineering - CSM 2018 Copyright $(\odot$ Institute of Research Engineers and Doctors, USA. All rights reserved. ISBN: 978-1-63248-150-4 doi: 10.15224/978-1-63248-150-4-25

\subsection{Seismic stimulation}

Seismic stimulation for the following analyses uses five historical acceleration recordings from the earthquakes of Kalamata (1986), Lefkada (2003), Kobe (1995), Northridge (1994) and Friuli (1976) [8]. Table 5 provides the key elements of historical records. Also, Figure 4 shows the Eurocode 8 spectrum calibrated for a maximum acceleration of $0.3 \mathrm{~g}$.

TABLE 5. HISTORICAL SEISMIC EXCITEMENT RECORDS

\begin{tabular}{|c|c|c|c|c|c|}
\hline $\begin{array}{l}\text { Earthquak } \\
\text { e }\end{array}$ & $\begin{array}{l}\text { Mag } \\
\text { nitu } \\
\text { de } \\
\text { Mw }\end{array}$ & $\begin{array}{l}\begin{array}{l}\text { Concen } \\
\text { tric }\end{array} \\
\text { Distanc } \\
\text { e } \\
\text { R (km) }\end{array}$ & $\begin{array}{l}\text { Recor } \\
\text { ding }\end{array}$ & $\begin{array}{l}\text { Comp } \\
\text { onent }\end{array}$ & $\begin{array}{l}\text { PGA } \\
\text { (g) }\end{array}$ \\
\hline $\begin{array}{l}\text { Kalamata } \\
(1986)\end{array}$ & 6.0 & 12 & $\begin{array}{l}\text { Prefect } \\
\text { ure }\end{array}$ & Hor. & $0.25 \mathrm{~g}$ \\
\hline $\begin{array}{l}\text { Lefkada } \\
(2003)\end{array}$ & 6.4 & 10 & $\begin{array}{l}\text { Lefkad } \\
\text { a }\end{array}$ & Trans. & $0.60 \mathrm{~g}$ \\
\hline $\begin{array}{l}\text { Kobe } \\
(1995)\end{array}$ & 7.2 & 20 & $\begin{array}{l}\text { Port } \\
\text { Island }\end{array}$ & $\begin{array}{l}\text { horizo } \\
\text { ntal }\end{array}$ & $0.57 \mathrm{~g}$ \\
\hline $\begin{array}{l}\text { Northridge } \\
\text { (1994) }\end{array}$ & 6.7 & 30 & Rinaldi & $\begin{array}{l}\text { Hor. } \\
318\end{array}$ & $0.47 \mathrm{~g}$ \\
\hline $\begin{array}{l}\text { Friuli } \\
\text { (1976) }\end{array}$ & 6.5 & 19 & Friuli & Hor. & $0.35 \mathrm{~g}$ \\
\hline
\end{tabular}

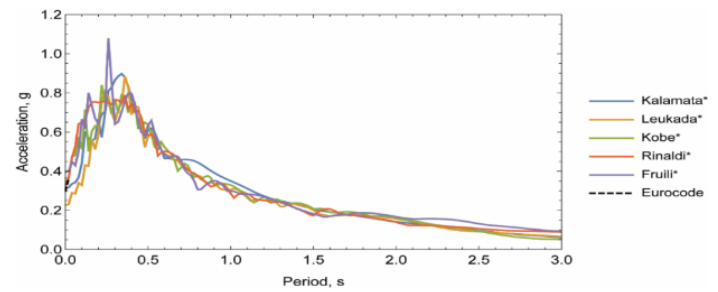

Figure 4. Sequencing responses of modified seismic stimuli and rock design according to the Eurocode 8. The stimuli were modified so that the acceleration spectrum would approach that of Eurocode 8.

\section{REPRESENTATIVE RESULTS OF PARAMETRIC ANALYSES}

This section presents representative results of seismic response and permanent displacements of extremities, on the three geometry cases given in figures 1,2 and 3, by mutual stimulation based on the Lefkada earthquake (2003). Aiming for comparable results of parametric analyses, we used geometry extremities and combinations of strength parameters that approximately lead to a minimum safety factor under the FS $=1.5$. Despite this, it is evident that there are significant fluctuations in the response and permanent displacement of the slopes due to the spatial variability of the soil properties.
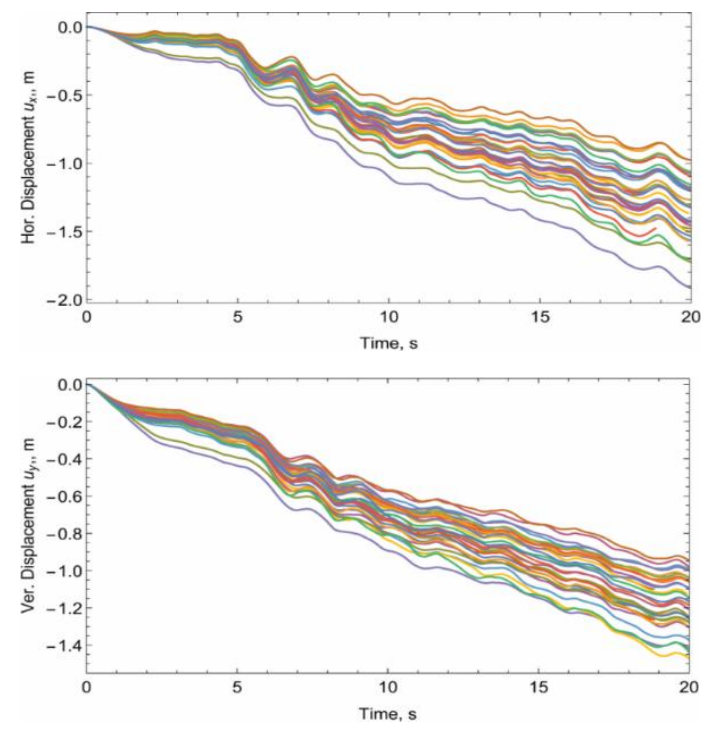

Figure 5. Geometry A: (a) horizontal and (b) vertical displacement at point $\mathrm{A}$.

TABLE 6. PERMANENT DISPLACEMENT OF SLOPES.

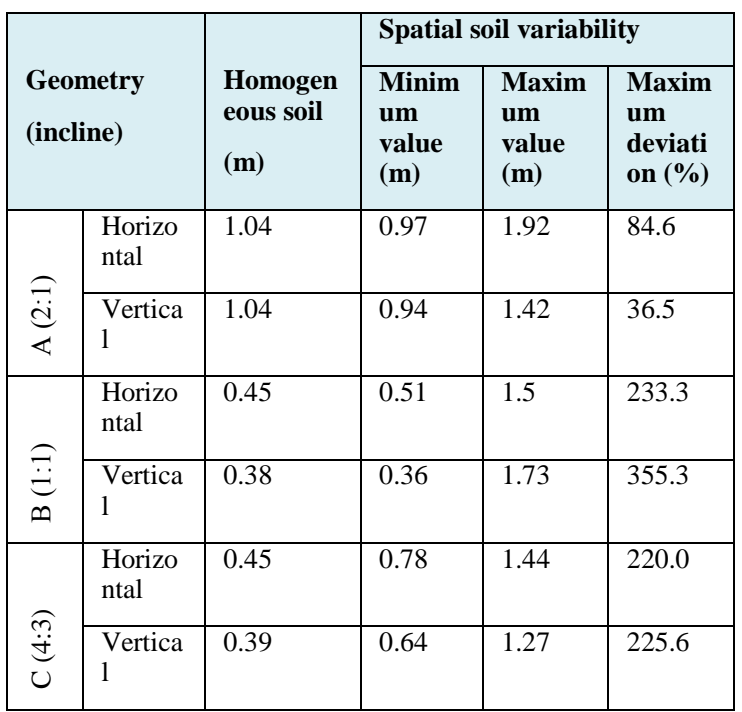

Figures $6,7,8$ show the results of permanent horizontal, vertical and total deformations at the end of seismic vibration for the 6 seismic intensity levels and the 5 seismic excitements examined. The change in the mean value of the permanent horizontal displacement can be approximated by the equation $f[x]=a x^{b} \quad$ (1) where $x$ is the ratio $a_{g} / g$ of the maximal acceleration of excitation $\left(\alpha_{\mathrm{g}}\right)$ to the acceleration of gravity (g), while $a$ and $b$ are parameters of the equation. 
Proc. of the Sixth Intl. Conf. Advances in Civil, Structural and Mechanical Engineering - CSM 2018

Copyright $(\odot$ Institute of Research Engineers and Doctors, USA. All rights reserved.

ISBN: 978-1-63248-150-4 doi: 10.15224/978-1-63248-150-4-25

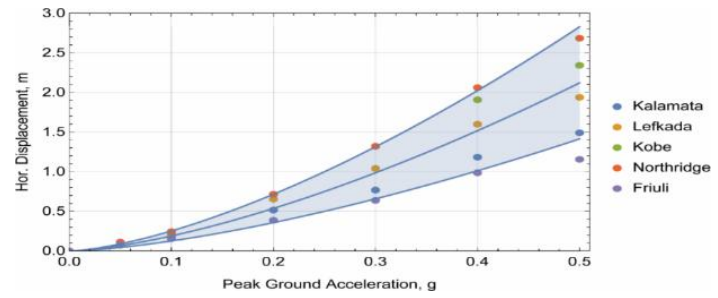

FIGURE 6: INFLUENCE OF THE MAXIMUM ACCELERATION AND THE FREQUENCY CONTENT OF THE STIMULATION ON THE PERMANENT HORIZONTAL DISPLACEMENT OF THE SLOPE CORNICE WITH A 2: 1 GRADIENT (POINT A) .

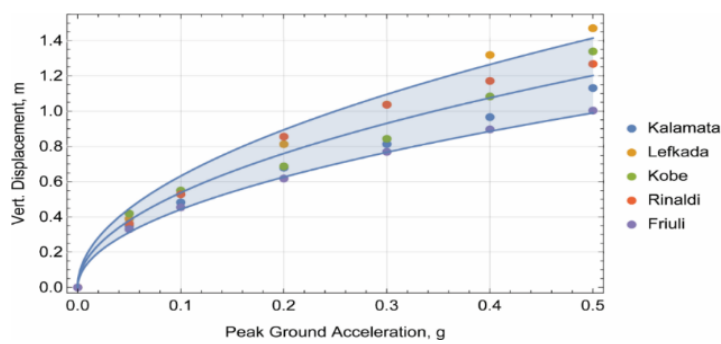

FIGURE 7: INFLUENCE OF THE MAXIMUM ACCELERATION AND THE FREQUENCY CONTENT OF THE EXCITATION ON THE PERMANENT VERTICAL DISPLACEMENT OF THE SLOPE CORNICE WITH A 2: 1 GRADIENT (POINT A) .

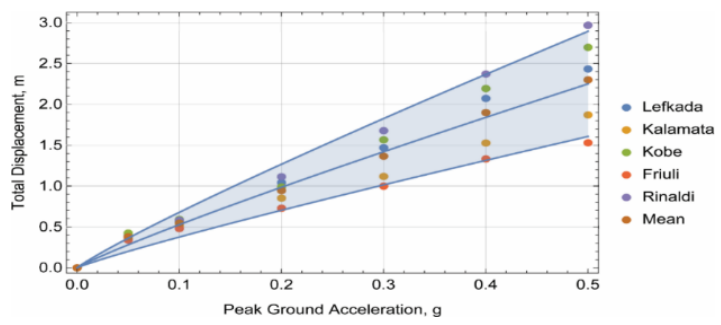

Figure 8: Influence of the maximum acceleration and the frequency content of the stimulation on the permanent total displacement of the slope with a 2:1 gradient (Point A)

\section{EFFECT OF SLOPE INCLINE}

The results of Table 7 are presented for the purpose of investigating the effect of slope incline on permanent displacements.

TABLE 7. SOIL PROPERTIES, STATIC SAFETY FACTOR AND MEAN VALUES OF PERMANENT DISPLACEMENTS OF HOMOGENEOUS SLOPES FOR THE FIVE SEISMIC STIMULI (PGA $=0.30 \mathrm{G})$

\begin{tabular}{|l|c|l|l|l|l|l|}
\hline $\begin{array}{l}\text { Inclination } \\
\text { of a slope }\end{array}$ & $\begin{array}{c}c, \\
\mathrm{kPa}\end{array}$ & $\phi^{\circ}$ & $\mathrm{FS}$ & $\begin{array}{c}\bar{u}_{x} \\
, \mathrm{~m}\end{array}$ & $\begin{array}{c}\bar{u}_{y} \\
, \mathrm{~m}\end{array}$ & $\bar{u}, \mathrm{~m}$ \\
\hline $2: 1$ & 50 & 30 & 2.58 & 0.39 & 0.35 & 0.53 \\
\hline $4: 3$ & 50 & 30 & 1.71 & 0.41 & 0.47 & 0.63 \\
\hline $1: 1$ & 50 & 30 & 1.45 & 0.76 & 0.54 & 0.94 \\
\hline
\end{tabular}

The following formulas show the probability density functions of the component permanent displacement $u$ for the three slope inclines, i.e. $2: 1,4: 3$ and 1:1. The best-described distributions are Weibull, Extreme Value and Gamma [9].

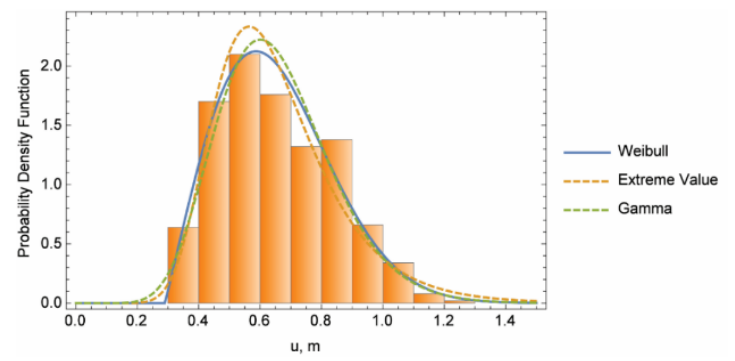

FIGURE 9: COMPONENT PERMANENT DISPLACEMENT $U$ FOR A 2:1 GRADIENT (PGA = $0.30 \mathrm{G})$

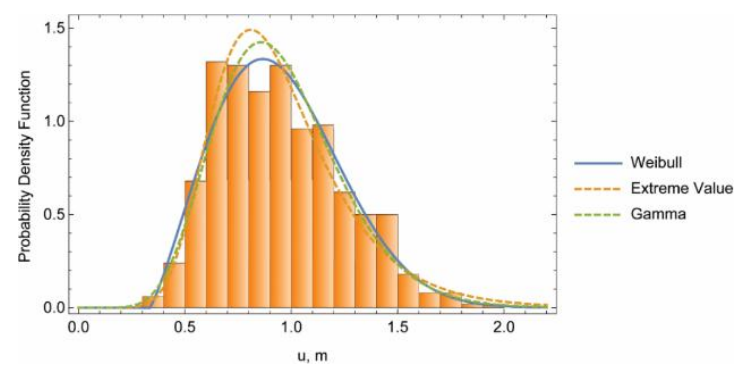

FIGURE 10: COMPONENT PERMANENT DISPLACEMENT $U$ FOR 4:3 (PGA $=0.30 \mathrm{G})$.

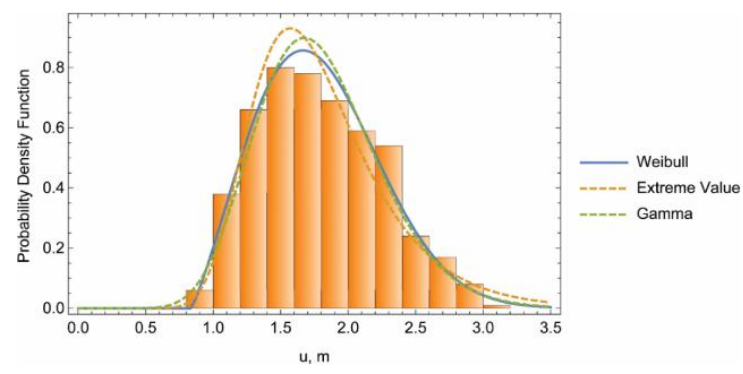

FIGURE 11: COMPONENT PERMANENT DISPLACEMENT $U$ FOR A 1:1 GRADIENT $(\mathrm{PGA}=$ $0.30 \mathrm{G})$.

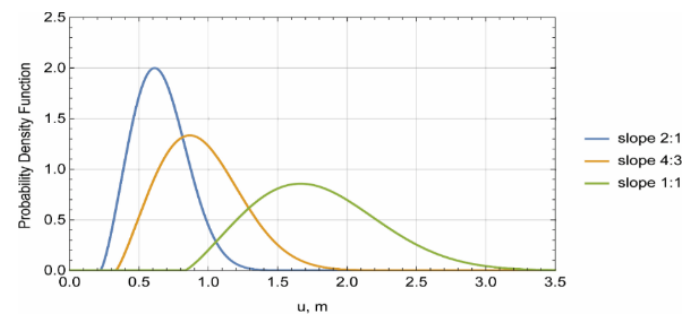

FIGURE 12: PROBABILITY DENSITY FUNCTION OF THE COMPONENT PERMANENT DISPLACEMENT $U$ FOR SLOPE SLOPES OF 2:1, 4:3 AND 1:1 (PGA = 0.30G).

\section{CONCLUSIONS}

1. The nonlinear variation of the seismic slope permanent displacement with the magnitude of the seismic intensity (ie the maximum acceleration $a_{g \text { max }}$ ) can be described with an exponential 
function of the form $a\left(\mathrm{a}_{g \max } / g\right)^{b}$, where $a, b$ are stable.

2. For a fixed value of seismic intensity, distribution of permanent displacement resulting from different seismic excitations follows an approximately uniform distribution. The effect of the frequency content of seismic excitation is important as it generates a range of variation of results equal to $\pm 40 \%$ in the case of horizontal displacement and $\pm 20 \%$ in the case of vertical displacement. However, it is desirable to increase the number of seismic stimuli with different frequency content for a better statistical description of the effect of the seismic excitation characteristics.

3. Regarding the effect of slope incline, the results show that, as slope incline increases, the mean and standard dispersion of permanent seismic displacement significantly increase.

4. The present investigation has shown that the calculation of rates of movement of slopes under seismic loading can be carried out pragmatically with probabilistic and stochastic methods. Differences in the response due to spatial variability of soil properties are quite significant. It is desirable for the parametric investigations of this research to be further extended in order to best describe the uncertainties and the overall conclusions to be reassessed in order to be taken into account in longterm regulatory provisions.

\section{REFERENCES}

[1] Alonso E.E., and Krizek R.J. (1975). Stochastic formulation of soil properties. In Proc. $2^{\text {nd }}$ Int Conf. on Application of Statistics and Probability in Soil and Structural Engineering, Aachen, volume 2, p.p. 9-32, 1975.

[1] Fortsakis P., Stylianidis E. and Kavvadas M. (2010). Stability of Slope Slopes using Stochastic Methods. 6th Panhellenic Conference of Geotechnical and Geoenvironmental Engineering, TEE, P.1-8.

[1] Alonso E.E. (1976). Risc analysis of slopes and its application to slopes in Canadian sensitive clays, Geotechnique, 26 (453-472), 1976.

[1] Babu S.G.L. and Mukesh M.O. (2004). Effect of soil variability on reliability of soil slopes. Geotechnique 54, No 5, p.p.335-337.

[1] Bray J.D. and Travasarou T. (2007). "Simplified procedure for estimating earthquake-induced deviatoric slope displacements." J. of Geotechnical and Geoenvironmental Engineering, ASCE, V. 133(4), pp. 381-392.

[1] Cho S.E. (2007). Effects of spatial variability of soil properties on slope stability. Eng Geol. 92 (34): p.p. 97-109.

[1] El-Ramly H., Morgestern N.R. and Cruden D.M (2002). Probabilistic slope stability analysis for practice. Canadian Geotechnical Journal, 39, p.p.665-683.

[1] Griffiths D.V., Huang J. and Fenton G.A. (2010). Probabilistic infinite slope analysis. (infoslope 2010), p.p. 1-3.

[1] Honjo Y., Suzuki M., Takashi H., Zhang F. (2009) Geotechnical Risk and Safety Proceedings of the 2nd International Symposium on Geotechnical Safety and Risk (IS-Gifu 2009) 11-12 June, 2009, Gifu, Japan - IS-Gifu2009.

[1] Honjo Y., Suzuki M., Takashi H., Zhang F. (2009) Geotechnical Risk and Safety Proceedings of the 2nd International Symposium on Geotechnical Safety and Risk (IS-Gifu 2009) 11-12 June, 2009, Gifu, Japan - IS-Gifu2009.

[1] Low B.K. (2003). Practical probabilistic slope stability analysis. In Proceedings, Soil and Rock America 2003, 12th Panamerican Conference on Soil Mechanics and Geotechnical Engineering and 39th U.S. Rock Mechanics Symposium, M.I.T., Cambridge, Mass, 22-26 June 2003. Verlag Glückauf GmbH Essen. Vol. 2, p.p. $2777-$ 2784

[2] Ambraseys N. and Menu J. (1988). Earthquake induced ground displacements. Earthquake Engineering and Structural Dynamics 16(7), p.p.985-1006.

[2] Ambraseys N. and Srbrulov M. (1995). Soil Dynamics and Earthquake Engineering. Earthquake induced displacements of slopes. Volume 14, issue 1, 1995, p.p.59-71.

[2] Bouckovalas G.D. and Papadimitriou A.G. (2005). Numerical evaluation of slope topography effects on seismic ground motion. Soil Dyn. And Earthquake Engng 25. p.p.547-558. 2005.

[2] Dakoulas P. (2005). Advanced Soil Mechanics (Elasto-plastic Constitutive Models for soils). Notes for the Graduate Course Advanced Soil Mechanics, University of Thessaly, Greece, 400 pages.

[2] Duncan J.M., Wright G.S., and Brandon T.L. (2014). Soil Strength and Slope Stability. Willey and Sons, New Jersey.

[2] Efremidis G., Avlonitis M., Konstantinidis A. and Aifantis E.C., (2015). "Realistic spring block models for earthquake-induced landslides", Proceedings of 13th International Congress on Rock Mechanics, 10-13 May, Montreal, Canada (2015), ISRM-13 Congress-2015-188.

[2] Malet J.P. and Maquaire O. (2006). Risk Assessment Methods of Landslides. Sixth Framework programme, scientific support to police p.p. 7-23.

[2] Pitilakis K. et al. (2010). Physical vulnerability of elements at risk to landslides Methodology for 
evaluation, fragility curves and damage states for building and lifelines. Deliverable 2.5 in EUFP7 research project No 226479 SafeLand Living with landslide risk in Europe: Assessment, effects of global change and risk management strategies.

[2] Pitilakis K. (2011). Fragility functions for roadway system elements. Seventh Framework programme. Task Leader, Norwegian Geotechnical Institute. p.p. 7-10, 15-18, 55-71.

[2] Pitilakis KD, (2010). Geotechnical Seismic Engineering. Ziti Publications. ISBN 960-456226-6.

[2] Komodromos A. (2008a). Soil-Construction Interaction. University of Thessaly, Volos, pp.6-7 and 18-57.

[2] Komodromos A. (2008b). Computational Geotechnical Engineering. Soil-Construction Interaction. Klidarithmos Publications, Athens, P.27-28, 88-92, 157-162 and 341-397.

[2] Huber M. (2013). Soil variability and its consequences. Institut für Geotechnik der Universität Stuttgart, Germany. p.p.1-9

[2] Safeland (2012). Living with landslide risk in Europe: Assessment, effects of global change, and risk management strategies

[3] Griffiths D.V. and Fenton G.A. (2007) Probabilistic methods in geotechnical engineering. CISM courses and lectures No 491, International centre for mechanical sciences, Springer Wien, New York

[3] Griffiths D.V. and Huang J. (2009). Influence of Spatial Variability on Slope Reliability Using 2-D Random Fields. Journal of Geotechnical and geoenviromental engineering ASCE/October 2009/ p.p 1367-1375.

[3] Dey A. (2014). Probabilistic Slope Stability Analysis Spatial Variability of Soil Properties Influence of Correlation Length. 14th International Conference of the International Association for Computer Methods and Advances in Geomechanics, Kyoto, Japan p.p.1-26.

[3] Fenton G.A., Griffiths D.V. and Urquhart A. (2003). A slope stability model for spatially random soils. In Proc. 9th Int. Conf. Applications of Statistics and Probability in Civil Engineering (ICASP9), A. Kiureghian et al. Eds Millpress, San Fransisco, CA, p.p 1263-1269.

[3] Travassarou Th. (2006). Probabilistic Methodology for the Calculation of Remaining Seismic Displacements in Slopes. Oakland, USA.5th Panhellenic Geotechnical Conference, TEE, Xanthi, P.1-8.

[3] Prakash S. and Dakoulas P. (1994). Grand failures under Seismic Conditions, American Society of Civil Engineers, New York, p.p. 260.

[3] Low B.K., Lacasse S., Nadim F. (2007). Slope reliability analysis accounting for spatial variation. Georisk: Assessment and Management of Risk for Engineered Systems and Geohazards 1(4): 177189

[3] Alamanis N.O (2017), Effect of spatial variability of soil properties in permanent seismic displacements of road slopes. Doctoral dissertation: University of Thessaly Department of
Civil Engineering, Geotechnical Engineering Sector p.p. 18-95, Supervisor: P. Dakoulas

[4] Fenton G.A. and Griffiths D.V. (2007). Random field generation and local average subdivision method. New York. CISM Courses and Lectures.

[4] Fenton A.G. and Vanmarcke E.H (1990). Simulation of Random Fields via Local Average Subdivision, Journal of Engineering Mechanics, Vol.116, No 8 p.p. 1733-1749.

[4] Fenton A.G. and Griffiths D.V. (2008). Risk Assessment in Geotechnical Engineering. John Viley and Sons, Inc. ISBN: 978-0-470-17820-1 p.p. $91-235,381-392$.

[4] Griffiths D.V. and Fenton G.A. (2004). Probabilistic slope stability analysis by finite elements. NSF Grant No CMS-9877189, p.p. 127.

[5] Dawson E.M., Roth W. H. and Dresner A. (1999). "Slope stability analysis by strength reduction", Geotechnique 49, No 6, p.p 835-840.

[5] Itasca Consulting Group, Inc. (2002). FLAC 4.0, Fast Langrangian Analysis of Continua, Users Guide FLAC-GIIC REFERENCE.

[5] Itasca. (2011). FLAC 7.0 Fast Langrangian Analysis of Continua. Users Guide Minneapolis Itasca Consulting Group.

[5] Itasca. FLAC /DEM Symposium. (2013). Continuum and Distinct Element Numerical Modeling in Geomechanics - 2013. Proceedings of the 3rd International FLAC /DEM Symposium October 22-24, 2013, HANGZHOU, P.R. CHINA.

[5] Malvern E.L. (1969). Introduction to the mechanics of a continuous medium. Prentice-Hall, Inc. Englewood Cliffs, New Jersey.

[5] Marti J. and P. A. Cundall. (1982). "Mixed Discretisation Procedure for Accurate Solution of Plasticity Problems," Int. J. Num. Meth. Eng., 6, 129-139 (1982).

[6] Wolfram S. (2008). Wolfram Mathematica. https//en.wikipedia.org/wiki/Wolfram Mathematica.

[6] Wolfram S. (2010). "The Mathematica Book" $4^{\text {th }}$ version 2000, Cambridge University Press.

[6] Athanasiou G. (2007). Guide to Mathematica software. University of Athens, EPEAEK II, p. 14.

[6] Themelis N. (2008). Notes on the Mathematica program. NTUA Athens.

[7] Rackwitz R. (2000). Reviewing probabilistic soils modeling. Elsevier Science Ltd. Computers and Geotechnics 26 (2000) p.p. 199-223.

[7] Wolff T.F. (1996). "Probabilistic slope stability in theory and practice" in Uncertainty in the Geological Enviroment, ASCE Proceedings of Special Conference, Madison, WI, p.p 419-433. Also, ASCE Geotechnical Special Publication 58.

[7] Wu Xing Zheng (2013). Trivariate analysis of soil ranking correlated characteristics and its application to probabilistic stability assessments in geotechnical engineering problems, Soils and Foundations, Volume 53, Issue 4, August 2013, p.p. 540-556. 
Proc. of the Sixth Intl. Conf. Advances in Civil, Structural and Mechanical Engineering - CSM 2018

Copyright (C) Institute of Research Engineers and Doctors, USA. All rights reserved.

ISBN: 978-1-63248-150-4 doi: 10.15224/978-1-63248-150-4-25

[8] Anagnostopoulos S.A., Rinaldis D, Lekidis V.A., Margaris V.N., Theodoulidis N. P. (1987). "The Kalamata, Greece, Earthquake of September 13, 1986", Earthquake Spectra, Vol.3, No 2, (1987), $365-402$.

[8] Fountoulis I. G. and Mavroulis S.D. (2013). Application of the Environmental Seismic Intensity Scale (ESI 2007) and the European Macroseismic Scale (EMS-98) to the Kalamata (SW Peloponnese, Greece) earthquake (MS=6.2, September 13,1986) and correlation with neotectonic structures and active faults, Annals of Geophysics, 56,6,2013, S0675,doi 10.4401/AG3237 p.p. $1-20$

[8] Friuli 1976. Earthquake. Civil Protection. Department photos et videos. https:www.protezionecivile.gov.it.

[8] Gazetas G., Dakoulas P. and Papageorgiou A. (1990). Local-Soil and Source-Mechanism Effects in the 1986 Kalamata (Greece) Earthquake, Journal of Earthquake Engineering and Structural Dynamics, Vol 19, p.p.431-456.

[8] https://en.wikipedia.org/wiki/1994-Northridgeearthguake.

[8] www.oasp.gr/node/497, Lefkada 2003.

[8] Kobe earthquake 1995, Great Hanshin Earthquake Restoration https://en.wikipedia. org/wiki/Great_Hanshin_earthquake.

[9] https://en.wikipedia.org/wiki/Weibull_distribution.

[9]

https://en.wikipedia.org/wiki/Generalized_extrem e_value_distribution.

[9] Koutras B.M., (2002). Introduction to Probability. Theory and applications. Athens 2002. 